\title{
Discovery of Nymphomyia larval remains (Insecta: Diptera: Nymphomyiidae) in five hundred year-old bottom sediments of Oron lake (Eastern Siberia, Russia)
}

\author{
I.V. Enushchenko1, E.A. Makarchenko² \\ ${ }^{1}$ Limnological Institute, Siberian Branch of the Russian Academy of Sciences, Ulan-Batorskaya str., \\ 3, Irkutsk,664033, Russia. E-mail: deschampsia@yandex.ru \\ ${ }^{2}$ Federal Scientific Center of the East Asia Terrestrial Biodiversity, Far Eastern Branch of the \\ Russian Academy of Sciences, 100 let Vladivostoku Ave., 159, Vladivostok, 690022, Russia. \\ E-mail:makarchenko@biosoil.ru
}

ABSTRACT: Finding of larval remnants belonging to archaic Diptera from the family Nymphomyiidae in Oron lake (Irkutsk Area, Bodaibinskiy District) bottom sediments is indicated for the first time. Remains of the larval head capsules are related to the recent group of species Nymphomyia gr. rohdendorfi, distributed mostly in the Russian Far East, as well as in south-eastern Asia and North America. A brief characterization of the location and morphological description of Nymphomyiidae remnants of the larval head are given and illustrated. The approximate period of time at which Nymphomyiidae inhabited Oron lake is established.

How to cite this article: Enushchenko I.V., Makarchenko E.A. 2019. Discovery of Nymphomyia larval remains (Insecta: Diptera: Nymphomyiidae) in five hundred year-old bottom sediments of Oron lake (Eastern Siberia, Russia) // Invert. Zool. Vol.16 No.3. P.219-225. doi: 10.15298/invertzool.16.3.02

KEY WORDS: Nymphomyia, fossils, Kodar ridge, Minor Ice Age, paleolimnology.

\section{Находка макроостатков личинок Nymphomyia (Insecta: Diptera: Nymphomyiidae) в 500-летних донных осадках озера Орон (Восточная Сибирь, Россия)}

\section{И.В. Енущенко 1 , Е.А. Макарченко ${ }^{2}$}

\footnotetext{
${ }^{I}$ Лимнологический институт СО РАН, ул. Улан-Баторская, 3, Иркутск 664033 Россия. E-mail: deschampsia@yandex.ru

${ }^{2}$ Федеральный научный центр биоразнообразия наземной биоть Восточной Азии ДВО РАН, nр. 100-летия Владивостока, 159, Владивосток690022 Pоссия.E-mail: makarchenko@biosoil.ru
}

РЕЗЮМЕ: Впервые отмечена находка макроостатков личинок, принадлежащих к архаичным двукрылым из семейства Nymphomyiidae в донных отложениях озера Орон (Иркутская область, Бодайбинский район). Останки обнаруженных головных головных капсул личинок близки современной группе видов Nymphomyia gr. rohdendorfi, распространенных в основном на Дальнем Востоке России, а также в юговосточной Азии и Северной Америке. Приведены и проиллюстрированы краткая характеристика места обнаружения макроостанков головных капсул личинок 
Nymphomyiidae и их морфологическое описание. Установлен приблизительный период времени, в который Nymphomyiidae обитали в озере Орон.

Как цитировать эту статью: Enushchenko I.V., Makarchenko E.A. 2019. Discovery of Nymphomyia larval remains (Insecta: Diptera: Nymphomyiidae) in five hundred year-old bottom sediments of Oron lake (Eastern Siberia, Russia) // Invert. Zool. Vol.16 No.3. P.219-225. doi: 10.15298/invertzool.16.3.02

КЛЮЧЕВЫЕ СЛОВА: Nymphomyia, осадки, Кодарский хребет, Малый ледниковый период, палеолимнология.

\section{Introduction}

The archaic dipteran family Nymphomyiidae is identified by the Japanese dipterologist M. Tokunaga (1932) on the basis of Nymphomyia alba Tokunaga, 1932, described by himself from the Kyoto University Botanic Garden(Honshu Island, Japan). These peculiar, minute and little-known flies are one of the most distinctive families of Diptera. They are easily recognized as larvae, pupae and adults (Courtney, 1994; Courtney, Jedlicka, 1997).

At present the world fauna of Nymphomyiidae includes only the genus Nymphomyia, including 9 species, 5 of which dwell in piedmont and montane watercourses of the Russian Far East - N. alba, N. kaluginae Makarchenko 2013, N. kannasatoi Makarchenko et Gunderina 2014, N. levanidovae Rohdendorf et Kalugina, 1974, and N. rohdendorfi Makarchenko, 1979 (Fig. 1). The species N. alba and N. kannasatoi inhabit Japanese streams, too (Makarchenko, 1996; Makarchenko et al., 2014; Saigusa, 2014). N. walkeri (Ide, 1965) inhabits North American streams (Back, Wood, 1979; Ide, 1964, 1965; Kevan, Cutten, 1975; Mingo, Gibbs, 1976; Smith et al., 1989) and N. dolichopeza Courthey, 1994 (USA) also occurs in North America; N. brundini (Kevan, 1970) inhabits India (West Bengal); and N. holoptica Courthey, 1994 (Saigusa, 2014) inhabits Hong Kong and possibly Japan. In addition, unidentified pupae of Nymphomyia sp. are found within the Northern Altai of Mongolia (Hayford, Bouchard, 2012). One species of fossil Nymphomyiidae - N. succina - is described based on remains of adults from Baltic and Bitterfeld amber (Wagner, Hoffeins et Hoffeins 2000).
Nymphomyiidae dwell in cold submontane and montane streams with rapid currents and high oxygen content in the water, low electric conductivity, and $\mathrm{pH}$ from weakly acid to weakly alkaline. Some species apparently can tolerate only a narrow range of environmental conditions; however, other species have been recorded from a variety of stream types, from small, clear, closed-canopy headwaters to large, brownwater rivers. Larvae typically settle on stony and gravel-pebble grounds which are frequently coved with algae in May and June. They often are found on moss-covered rocks. After emergence the Nymphomyiidae imago swarm at a height of 1-5 m creating swarms of some hundred individuals. Copulating midges land on damp stones in current or on a water surface, lose wings, submerge and for some time they live on the water body bottom or on inshore stones. Then females oviposit and frequently the female glues the eggs on the male abdomen end (Makarchenko, Gunderina 2019). Nymphomyiidae swarming occurs in the evening, often at sunset and in calm weather. Currently, the species biology is studied best for North American N. walkeri (Cutten, Kevan, 1970; Kevan, Cutten, 1975; Mingo, Gibbs, 1976; Back, Wood, 1979; Adler et al., 1985; Harper, Lauzon, 1989) and north-eastern palaearctic N. levanidovae (Makarchenko, Makarchenko, 1983), N. kannasatoi (Makarchenko et al., 2014) and N. rohdendorfi (Yarovskaya, Makarchenko, 2015), and to a lesser degree for N. alba (Takemon, Tanida, 1994; Saigusa et al., 2009).

Data on the larval morphology of different Nymphomyiidae species are published in several papers (Cutten, Kevan, 1970; Courtney, 1994; Takemon, Tanida, 1994; Courtney, Jedlicka, 


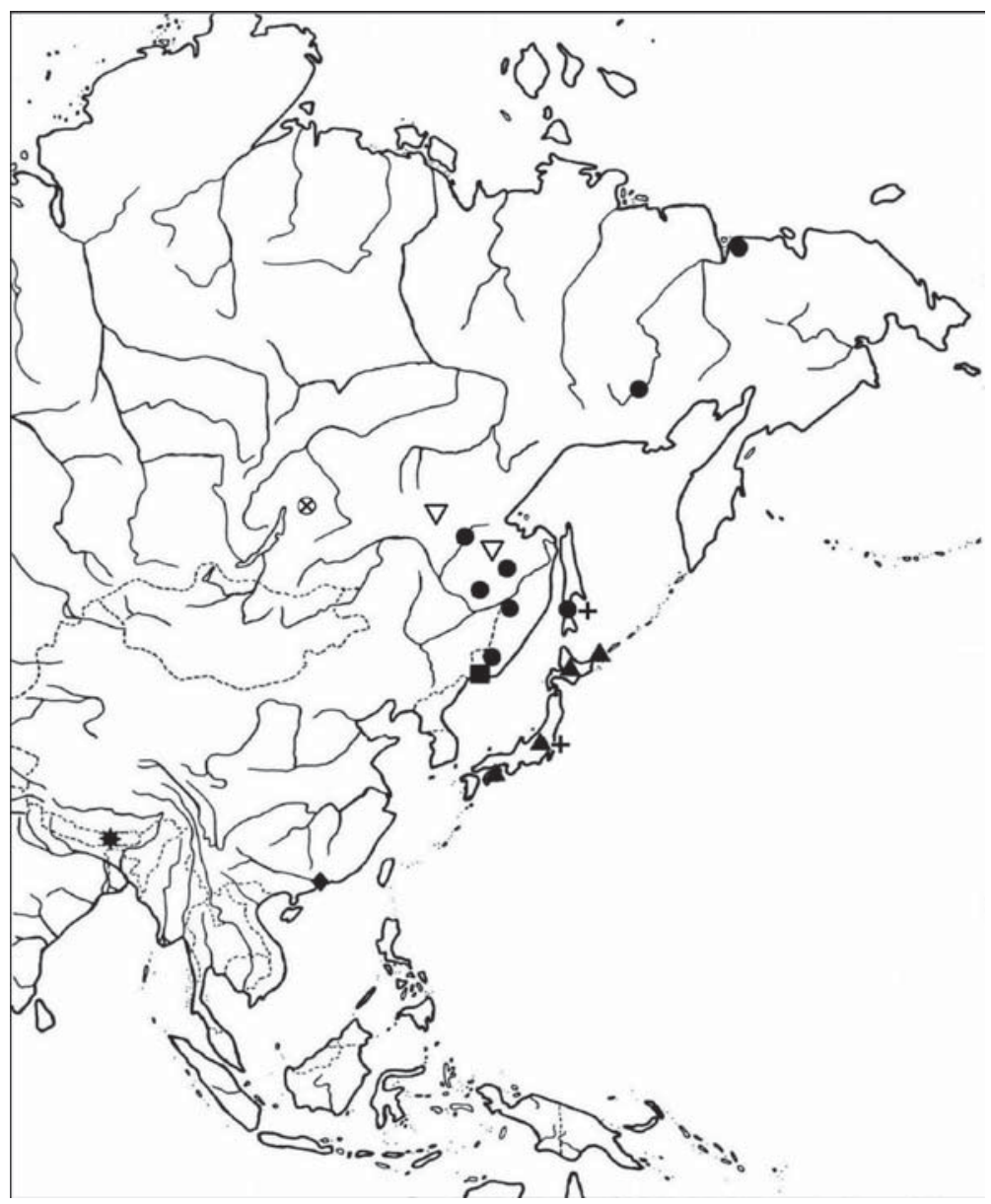

Fig. 1. Distributions of Palaearctic and Oriental species of Nymphomyia: N. alba (black triangle); N. kaluginae (inverted triangle); $N$. kannasaroi (cross); N. levanidovae (square); $N$. rohdendorfi (circle); $N$. brundini (star); N. holoptica (diamond) (Courtney, 1994; Makarchenko 2013; Makarchenko, Gunderina, 2019). Location, where remains of the Nymphoiya sp. larvae were found is marked by a circle with a cross. Рис. 1. Распространение видов Nymphomyia Палеарктики и Ориентальной области: N. alba (черный треугольник); N. kaluginae (перевернутый треуголник); N. kannasaroi (крест); N. levanidovae (квадрат); N. rohdendorfi (круг); N. brundini (звезда); N. holoptica (ромб) (Courtney, 1994; Макарченко 2013; Макарченко, Гундерина, 2019). Место, где в озере Орон были обнаружены макроостатки личинок Nymphoiya sp., обозначено крестом в круге.

1997; Makarchenko, 2006). Larvae are vermiform, their body is composed of 13 well distinguishable segments. Abdominal segments IVII and IX bear pairs of long pseudopodia at the apex of which a claw and crochets. The head is egg-shaped, pale-yellow; it bears a pair of larval eyelets near a posterior end. Antennae are shorter than half of the head length; the basal joint is erect, cylindrical, the distal series is composed of 4 short flat adnexa. The head bears a sharply protruding front projection formed by the clypeus, labrum and premandibles. The mandibles are in the form of a scoop with 7 teeth on the edge. The pamprodactylous mentum edge is dentate: the medial tooth is three- or five-lobed, there are five teeth on each side. Hypopharynx 


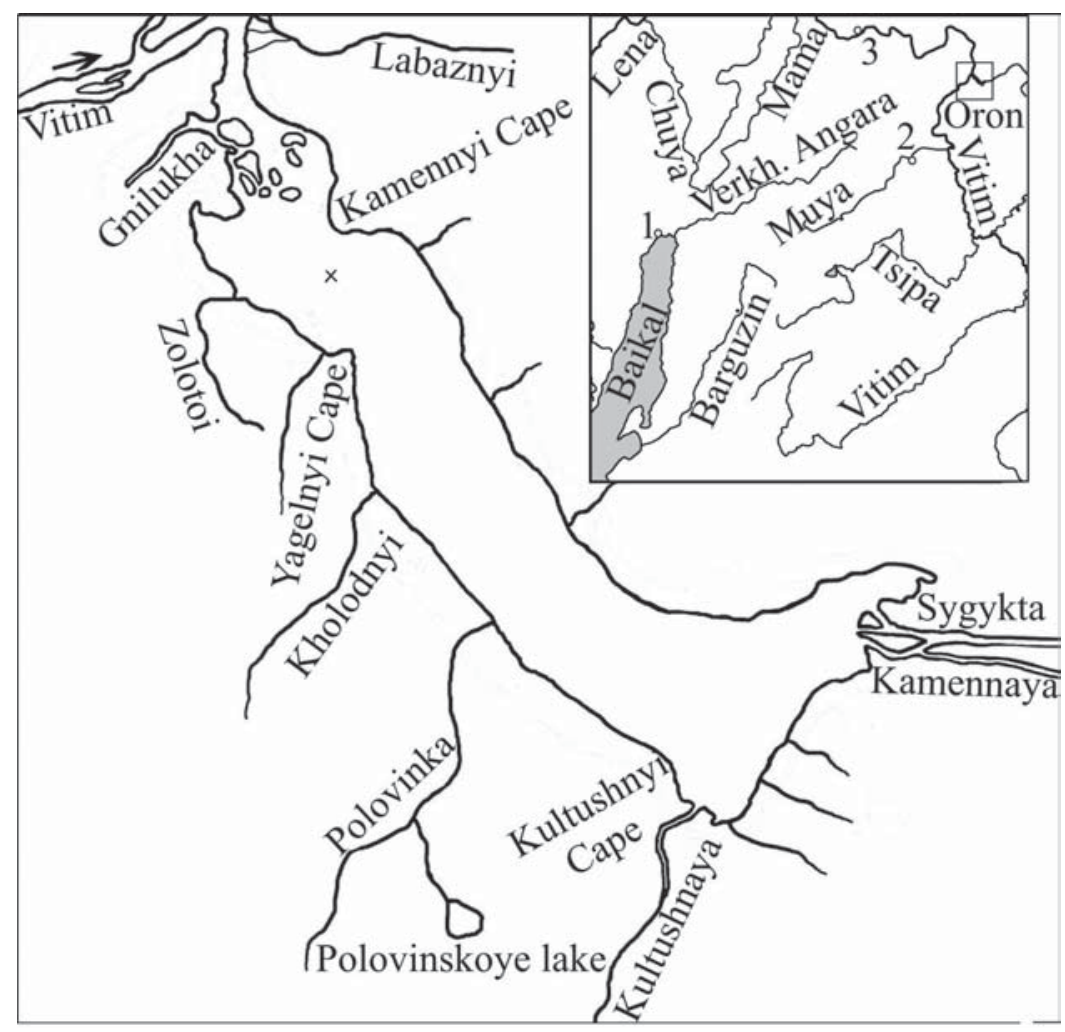

Fig. 2. Geographic location of Oron lake; position of analyzed core with Nymphoiya sp. larvae remains marked by cross. 1 - Nizhneangarsk; 2 - Taksimo; 3 - Bodaibo.

Рис. 2. Географическое положение озера Орон; место отбора керна, в котором были обнаружены макроостатки личинок Nymphoiya sp. обозначено крестом. 1 - Нижнеангарск; 2 - Таксимо; 3 Бодайбо.

is on apex with crest of narrow long dens. Larvae are mobile; they move over rocks using the abdominal pseudopodia, and sometimes use caddisfly cases (Trichoptera). Nymphomyiidae of several species in the larval stages can be situated in substreamflow; they go into the current just before pupation (Makarchenko, Gunderina, 2019). They eat diatoms, bacteria and fine organic material which they scrape off the stone surface. Pupae and adults do not eat.

As to internal anatomic features of Nymphomyiidae they are the following: the presence of a closed tracheal system and 8 free thoracic ganglia and a very large supraesophageal ganglion in the adult. Karyological studies were made only for $N$. levanidovae. The diploid number of this species is $2 \mathrm{n}=8$ (Makarchenko, 2006).
During core treatment of the Oron lake bottom sediments (Or-02/13), we found the remains of head capsules of Nymphomyiidae larvae. Up to the present the finding of fossil remains of the Nymphomyiidae preimago stage of development has not been mentioned.

\section{Materials and methods}

The Oron lake is situated in the northern part of the Baikal rift zone at a height of 353 meters above sea level, about $450 \mathrm{~km}$ from Lake Baikal (Fig. 2). The lake is bordered in the south and east by the Olekma-Vitim upland and in the west and north it is bounded by branches of the Kodar ridge which ranges in altitude from 1400-1800 m. 

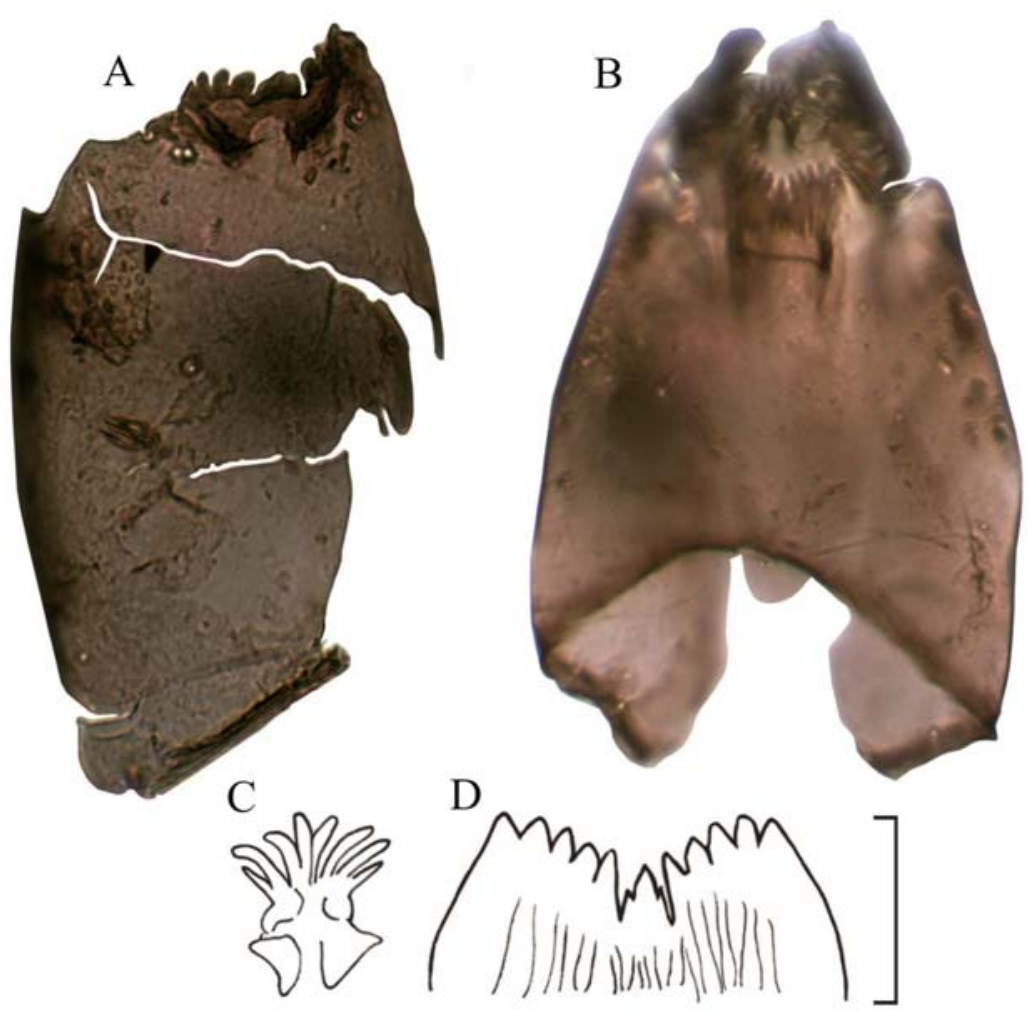

Fig. 3. Remains of Nymphoiya sp. larvae from Oron lake bottom sediments (A, B) and details of larvae head capsules (C, D). A — head capsule from horizon 13-14 cm; B — head capsule from horizon 26-27 cm; C hypopharynx; D - mentum. Scale bar $0.2 \mathrm{~mm}$.

Рис. 3. Макроостатки личинок Nymphoiya sp. из донных осадков озера Орон (A, В) и детали головных капсул личинок $(\mathrm{C}, \mathrm{D})$. A - головная капсула из горизонта 13-14 cм; В - головная капсула из горизонта 26-27 см; C — гипофаринкс; D — ментум. Линейка 0,2 мм.

The lake is of tectonic origin. Its length is 24 $\mathrm{km}$; width is $6.5 \mathrm{~km}$ and maximum depth is 184 m. The lake area is about $51.3 \mathrm{~km}^{2}$; its catchment basin area is $3570 \mathrm{~km}^{2}$ (Matveev et al., 2006). The Sygykta, Kultushnaya and Kamennaya Rivers, which spring from the Kodar ridge, are the main tributaries. In addition, more than 100 small rivers and rivulets flow into the lake.

In March 2013 the first author (as a member of the Limnological institute of the SB RAS (Irkutsk) expedition) sampled bottom sediments. Sampling was realized in a cross-section of the

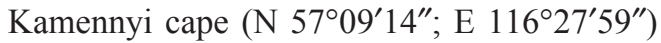
by the benthos sampler Uwitec-Corer from the depth of $9 \mathrm{~m}$. The taken core length was $73 \mathrm{~cm}$. The core upper part (0-2 aleuropelites $9 \mathrm{~cm})$ is generally presented by fine-grained olive greenbrown aleuropelites. The rest is composed of pale brown aleuropelites with abundant inclusions of phytodetritus (Fedotov et al., 2016), which indicates the different sedimentation rates at different time intervals. The depth-age model was developed on the basis of the isotope activity distribution of ${ }^{210} \mathrm{~Pb},{ }^{37} \mathrm{Cs}$ (Vorobyeva et al., 2015; Fedotov et al., 2016). CRS (Central Rate of Supply) the accumulation model of ${ }^{210} \mathrm{~Pb}$ (Binford, 1990) was used for the age calculation.

Only two head capsules of Nymphomyiidae larvae were found: in $13-14$ and $26-27 \mathrm{~cm}$ of the Or- $02 / 13$ core. Their short description is below. 


\section{Results and discussion}

The recovered head capsules with a form typical for the Nymphomyiidae larvae are brown (Fig. 3A, B). The hypopharynx is wide at the base with crest of 8 long and narrow teeth on the apex (Fig. 3C). Mentum with triple median tooth and five pairs of lateral teeth, roughly of the same size; the first lateral teeth almost of the same height with the rest of lateral teeth (Fig. 3D).

According to isotopic dating the core upper $9 \mathrm{~cm}$ were formed after 1870 . If you extrapolate the depth-age model to the core horizons from which the Nymphomyiidae larvae remains were extracted, it turns out that these horizons were formed around 1780 and 1500, respectively. That is it happened during so-called Minor Ice Age which ended in the second half of the 19th century. Then, the period of Recent Warming started, and it continues up to present. However, judging by the core lithologic structure character in this interval, these horizons are probably more ancient. Unfortunately, the discovered remains are not enough to a detailed comparison of fossil larvae with recent species; however, according to the hypopharynx and mentum texture they are suggested to be close to the larvae of recent species Nymphomyia gr. rhodendorfi, which are abundant in the Russian Far East (Yavorskaya, Makarchenko, 2015). It is possible that the archaic dipteran Nymphomyiidae currently inhabit the Oron lake basin which may be detected during more detailed hydrobiologic surveys of streams falling into the lake.

\section{Acknowledgements}

We wish to thank A.P. Fedotov (Limnological Institute, Siberian Branch of Russian Academy of Science, Irkutsk) for organization of the expedition in 2013 and his participation in it. Hearty thanks to V.A. Isaev, $†$ S.V. Nikishin, $†$ M.A. Rogov, O.A. Zamulin and P.I. Starozhuk (Vitimskiy State Nature Reserve, Bodaibo) for their help in sampling bottom sediment core from Oron lake and assistance in expediting work in the reserve. Hearty thanks to Alfred Newton (Chicago, USA) for correction of the English text of manuscript.

The work was supported in part by the Russian Foundation for Basic Research (projects no. 16-05-
00342, 17-29-05016 and 19-05-00668) and Federal Agency for Scientific Organizations 0345-20160006(AAAA-A16-116122110063-0).

\section{References}

Adler P.H., Light R.W., Cameron E.A. 1985. Habitat characteristics of Palaeodipteron walkeri (Diptera, Nymphomyiidae) // Entomol. News. Vol. 96. No.5. P.211-213.

Back C., Wood D.M. 1979. Palaeodipteron walkeri (Diptera, Nymphomyiidae) in Northern Quebec // Can. Ent. Vol.111. P.1287-1291.

Binford M.W. 1990. Calculation and uncertainty analysis of $210 \mathrm{~Pb}$ dates for PIRLA project cores // J. Paleolymnol. Vol.3. P.253-267.

Courtney G.W. 1994. Biosystematics of the Nymphomyiidae (Insecta, Diptera): life history, morphology, and phylogenetic relationships // Smiths. Contribut. Zool. No.550. P.1-39.

Courtney G.W., Jedlicka L. 1997. 2.2. Nymphomyiidae // L. Papp, B. Darvas (eds.). Manual of Palaearctic Diptera. Vol.2. Budapest: Science Herald. P.21-27.

Cutten F.E.A., Kevan D.K.McE. 1970. The Nymphomyiidae (Diptera), with special reference to Palaeodipteron walkeri Ide and its larva on Quebec, and a description of a new genus and species from India // Can. J. Zool. Vol.48. No.1. P.1-24.

Fedotov A.P., Vorobyeva S.S., Bndarenko N.A., Tomberg I.V., Zhuchenko N.A., Sezko N.P., Stepanova O.G., Melgunov N.S., Ivanov V.G., Zheleznyakova T.O., Shaburova N.I., Chechetkina L.G. 2016. [The effect of natural and anthropogenic factors on the evolution of remote lakes in East Siberia for the last 200 years] // Geol. Geophys. Vol.57. No.2. P.394-410 [in Russian].

Harper P.P., Lauzon M. 1989. Life cycle of the nymph fly Palaeodipteron walkeri Ide 1965 (Diptera, Nymphomyiidae) in the white mountains of southern Quebec // Can. Entomol. Vol.121. P.603-607.

Hayford B., Bouchard W. 2012. First record of Nymphomyiidae (Diptera) from Central Asia with notes on novel habitat for Nymphomyiidae // Proc. Entomol. Soc. Wash. Vol.114. No.2. P.186-193.

Ide F.P. 1964. A fly of the archaic family Nymphomyiidae found in New Brunswick in 1961 // Can. Ent. Vol.96. P.119-120.

Ide F.P. 1965. A fly of the archaic family Nymphomyiidae from North America // Can. Entomol. Vol.97. P.496507.

Kevan D.K.McE., Cutten-Ali-Khan F.E.A. 1975. Canadian Nymphomyiidae (Diptera) // Can. J. Zool. Vol.53. P.853-866.

Makarchenko E.A. 1996. Some remarks on Distribution of the Far Eastern Nymphomyiidae (Diptera) // Makunagi. Acta Dipterol. No.19. P.22-25.

Makarchenko, E.A. 2006. [Fam. Nymphomyiidae - Nymphomyiid fly] // A.S. Leley (ed.). [Key to the insects of Russian Far East]. Vol.6. Diptera and Siphonaptera. 
Pt.4. Vladivostok: Dalnauka. P.734-739 [in Russian, with English summary].

Makarchenko, E.A. 2013. [Nymphomyia kaluginae sp. n. - a new species of archaic Diptera (Nymphomyiidae) from Amur River basin (Russian Far East)] // Euroasian Ent. J. Vol.12. No.3. P.291-296 [in Russian, with English summary].

Makarchenko E.A., Gunderina L.I., Sato S. 2014. [Morphological description and DNA barcoding of Nymphomyia kannasatoi sp. n. (Diptera, Nymphomyiidae) from Japan and South of Sakhalin Island, with data on biology of species] // Euroasian Ent. J. Vol.13. No.6. P.535-544 [in Russian, with English summary].

Makarchenko E.A., Gunderina L.I. 2019. [Review of the archaic Nymphomyiid fly (Diptera, Nimphomyiidae) in the Far East and the adjacent territoriy, with $\mathrm{Nym}$ phomyia alba Tokunaga and N. levanidovae Rohdendorf et Kalugina morphologically and molecular-genetically redescribed] // Byulleten Severo-Vistochnogo nauchnogo tsentra DVO RAN. No.1. P. 72-82 [in Russian, with English summary]

Matveev A.N., Samusenok V.P., Rozhkova N.A., Bondarenko N.A., Kravtsova L.S., Sheveleva N.G., Slugina Z.V., Yuryev A.L. 2006. [The biota of the Vitim Nature Reserve: Biota structure in aquatic ecosystems]. Novosibirsk: Geo Sci. Press. 267 p. [in Russian]

Mingo T.M., Gibbs K.E. 1976. A record of Palaeodipteron walkeri Ide (Diptera, Nymphomyiidae) from Maine: a species and family new to the United States // Ent. News. Vol.87. P.184-185.

Saigusa T., Nakamura T., Sato S. 2009. Insect Mistswarming of Nymphomyia species in Japan // Fly Times. No.43. P.2-8.
Smith M.E., Wyskowski B.J., Driscoll C.T., Brooks C.M., Cosentini C.C. 1989. Palaeodipteron walkeri (Diptera, Nymphomyiidae) in the Adironback Mountains, New York // Entomol. News. Vol.100. P.122-124.

Takemon Y., Tanida K. 1994. New data on Nymphomyia alba (Diptera, Nymphomyiidae) from Japan with notes on the larvae and the micro-habitat // Aquatic Insects. Vol.16. P.119-124.

Yarovskaya N.M., Makarchenko E.A. 2015. [New data on taxonomy, distribution and biology of archaic Diptera Nymphomyia rhodendorfi Makarchenko, 1979 (Diptera, Nymphomyiidae)] // Euroaz. Ent. Zhurn. Vol.14. No.6. P.523-531 [in Russian, with English summary] Saigusa T. 2014. Family Nymphomyiidae. In: Nakamura T., Saigusa T., Suwa M. (Eds): Catalogue of the Insects of Japan. Diptera. Vol.8. Pt.1. NematoceraBrachycera Aschiza. The Entomological Society of Japan. Touka Shodo, Fukuoka. P. 80-81.

Tokunaga M. 1932. A remarkable Dipterous insect from Japan, Nymphomyia alba, gen. et sp. nov. // Ann. Zool. Japon. Vol.13. P.559-569.

Vorobyeva S.S., Trunova V.A., Stepanova O.G., Zvereva V.V., Petrovskii S.K., Melgunov M.S., Zheleznyakova T.O., Chechetkina L.G., Fedotov A.P. 2015. Impact of glacier changes on ecosystem of proglacial lakes in high mountain regions of East Siberia (Russia) // Envir. Earth Sci. Vol.74. P.2055-2063.

Wagner R., Hoffeins C., Hoffeins H.W. 2000 A fossil nymphomyiid (Diptera) from the Baltic and Bitterfeld amber // Syst. Entomol. Vol.25. P.115-120.

Responsible editor K.G. Mikhailov 